УДК 378.112(477)

DOI https://doi.org/10.32782/apv/2021.6.25

\title{
Ольга ОСЕРЕДЧУК
}

кандидат історичних наук, керівник Центру маркетингу та розвитку, дочент кафедри загальної педагогіки та педагогіки вищої школи, Львівський національний університет імені Івана Франка, вул. Університетська, 1, м. Львів, Україна, 79000

ORCID: 0000-0002-3192-3129

Бібліографічний опис статті: Осередчук, О. (2021). Методи та інструменти збору інформації про якість освіти. Acta paedagogika volynienses, 6, 161-167, doi: https://doi.org/10.32782/apv/2021.6.25

\section{МЕТОДИ ТА ІНСТРУМЕНТИ ЗБОРУ ІНФОРМАЦЇ̈ ПРО ЯКІСТЬ ОСВІТИ}

У статті показано, що моніторинг освітнього процесу є важливим елементом системи забезпечення якості освітньої діяльності та вищої освіти в Україні. Важливе значення у вдосконаленні системи моніторингу має вибір методів збору інформачї про якість освіти.

Виокремлено різноманітні групи методів моніторингу, щз використовуються для діагностування якості освіти: метод поточного спостереження використовується для з 'ясування змін, які відбуваються у професійному розвитку особистості, щчо зумовлені освітнім процесом; метод тестових навчальних ситуацій, суть якого полягає у педагогічному створенні необхідних умов, дозволяє організувати навчальну діяльність, активізувати і структурувати їі; метод бесіди (співбесіди) дає можливість отримати інформацію про сформованість у тих, хто навчається, основних компонентів навчальної діяльності; графічні матеріали, творчі роботи, технічні вироби слухачів необхідні для аналізу результатів освітньо-професійної діяльності; тестування застосовується для зіставлення отриманих даних із середньостатистичними і є найбільш ефективним методом збору інформації під час моніторингу; комплексний, синтетичний аналіз інформащії, який є першочерговим кроком на шляху визначення иілей $і$ способів їх досягнення; аналіз проблем - метод, щзо полягає у з'ясуванні різниці між об'єктом, де проблема існує, й іншим, схожим на нього об'єктом, де такої проблеми немає; аналіз сил впливу, що дає змогу швидко і наочно охарактеризувати загальну ситуачію, яка виникла; метод "Дерева иілей» - че прочес моніторингу, спрямований на знаходження пріоритетів вирішення проблем із погляду важливості та терміновості їх вирішення; метод оцінки пріоритетів проблем дає змогу з погляду важливості, невідкладності тендениій розвитку (погіршення або поліпшення) якості освіти визначити пріоритети проблем, щчо визначаються за допомогою відповідної табличі експертних оцінок.

Вагомими є методи, які дають можливість отримати інформаџію безпосередньо від респондента (первинні дані), яка характеризується новизною: спостереження, опитування (анкетування та інтерв'ювання), тестування, вибірковий метод, які здобули найбільше поширення, вони охарактеризовані у статті.

Ключові слова: методи, інструменти збору інформації, якість освіти, моніторинг освітнього процесу, групи методів, діагностування якості освіти.

\section{Olga OSEREDCHUK}

Candidate of Historical Sciences, Head of the Center for Marketing and Development, Associate Professor at the Department of General Pedagogy and Higher School Pedagogy, Ivan Franko National University of Lviv, University str., 1, Lviv, Ukraine, 79000

ORCID: 0000-0002-3192-3129

To cite this article: Oseredchuk, O. Metody ta instrumenty zboru informatsii pro yakist osvity [Methods and means of collecting information about the quality of education]. Acta paedagogika volynienses, 6 , 161-167, doi: https://doi.org/10.32782/apv/2021.6.25

\section{METHODS AND MEANS OF COLLECTING INFORMATION ABOUT THE QUALITY OF EDUCATION}

The article shows that the monitoring of the educational process is an important element of the quality assurance system of educational activities and higher education in Ukraine. The choice of methods for collecting information on the quality of education is important in improving the monitoring system.

There are various groups of monitoring methods used to diagnose the quality of education: the method of current monitoring is used to determine the changes that occur in the professional development of the individual, due to 
the educational process; the method of test learning situations, the essence of which is the pedagogical formation of the necessary conditions, allows you to organize learning activities, activate and structure it; the method of conversation (interview) gives the opportunity to obtain information about the formation of students in the main components of educational activities; graphic materials, creative works, technical products of students are necessary for the analysis of results of educational and professional activity; testing is used to compare the obtained data with the average and is the most effective method of collecting information during monitoring; comprehensive, synthetic analysis of information, which is a priority step towards defining goals and ways to achieve them; problem analysis, a method of finding out the difference between an object where a problem exists and another similar object where there is no such problem, ie; analysis of the forces of influence, which allows you to quickly and clearly describe the overall situation that has arisen; The goal tree method is a monitoring process aimed at finding priorities for solving problems in terms of the importance and urgency of solving them; The method of assessing the priorities of problems allows in terms of importance, urgency of development trends (deterioration or improvement) of the quality of education to determine the priorities of problems identified by the relevant table of expert assessments.

Important are the methods that allow to obtain information directly from the respondent (primary data), which is characterized by novelty: observations, surveys (questionnaires and interviews), testing, sampling method, which are the most common, which are described in the article.

Key words: methods, tools of information gathering, quality of education, monitoring of educational process, groups of methods, diagnosing quality of education.

Постановка наукової проблеми таїїначення. Моніторинг якості освіти є одним з інструментів модернізації змісту вищої освіти, вдосконалення її організації, що має забезпечити підвищення якості підготовки фахівців.

Аналіз останніх досліджень і публікацій. Моніторинг якості вищої освіти розглядали С. Вербицька, М. Кісіль, О. Локшина, Т. Лукіна, О. Ляшенко, О. Ніколенко, О. Островерх, В. Приходько, О. Родіонов, Л. Сєркова, М. Скиба, І. Соколова, О. Туржанська, Г. Хімічева, Т. Хоруженко, С. Хриков, Н. Чайкіна та інші.

Моніторинг освітнього процесу $\epsilon$ важливим елементом системи забезпечення закладами вищої освіти якості освітньої діяльності та вищої освіти в Україні, що стало одним 3 основних завдань Національного агентства із забезпечення якості вищої освіти (НАЗЯВО).

Мета статті - охарактеризувати методи та інструменти збору інформації про якість освіти.

Виклад основного матеріалу. Важливе значення у вдосконаленні системи моніторингу має вибір методів збору інформації про якість освіти.

У процесі моніторингу використовуються різноманітні групи методів. М. Євтух, Е. Лузік, Л. Дибкова найголовнішими вважають наведені нижче.

Метод поточного спостереження використовується для 3'ясування змін, які відбуваються у професійному розвитку особистості, що зумовлені освітнім процесом.

Метод тестових навчальних ситуацій, суть якого полягає у педагогічному утворенні необхідних умов, дає змогу організувати навчальну діяльність, активізувати і структурувати ії. Цей метод застосовується для найбільш повного прояву кожного зі структурних компонентів навчально-професійної діяльності. Під час його застосування використовуються такі прийоми, як: переривання навчальних дій; постановка уточнювальних запитань; правильні і неправильні підказки; стимулювання рефлексії власних дій, дозування допомоги в навчанні тощо.

Метод бесіди (співбесіди) дає можливість отримати інформацію про сформованість у тих, хто навчається, основних компонентів навчальної діяльності, про особливості педагогічної спрямованості слухачів і педагогів, про властивості, яких набули слухачі, і якості, які отримали.

Графічні матеріали, творчі роботи, технічні вироби слухачів необхідні для аналізу результатів освітньо-професійної діяльності. Із необхідністю модернізації вищої освіти, вдосконалення iii змісту і технологій відбувається наростання соціальних, культурних, інформаційних, економічних, духовних змін.

Тестування застосовується для зіставлення отриманих даних із середньостатистичними. Тести є одним із найбільш ефективних методів збору інформації у процесі моніторингу і дають можливість отримувати повну, точну, своєчасну інформацію про ступінь відповідності кінцевих результатів навчання заданим. Під час моніторингу використовуються: практичні тестові завдання, інтелектуальні, особистісні, міжособистісні, процесуальні тести (Свтух, 2010).

Підкреслюючи те, що функціонально методи мають забезпечити високу ефективність моніторингу педагогічного процесу, В. Приходько 
зазначає, що різні методи у разі їх правильного застосування відрізняються надійністю, точністю, об'єктивністю отриманої інформації.

Надійність отриманої інформації уможливлює достовірність результатів дослідження, що показує якість відповідності зроблених висновків реальному стану об'єкта, що досліджується.

Точність методу визначає мінімальну або систематичну похибку, яка допустима під час проведення вимірювання запропонованим методом.

Об'єктивність є основною вимогою до відбору методу для збору інформації під час моніторингу, досягається шляхом мінімуму впливу суб'єктивних факторів і забезпечується стандартизацією умов вимірювання: об'єктивністю проведення вимірювання, об'єктивністю обробки даних, об'єктивністю інтерпретації результатів.

Кожен зметод має свої обмеження, об'єктивні недоліки, тому не може бути універсальним. Варто застосовувати різні методи збору інформації у поєднанні. Зокрема, методи, що забезпечують отримання нових даних, і методи, що надають відомості з інших статистичних джерел інформації (Приходько, 2010).

Н. Пугачова пропонує методи моніторингу якості освіти, наведені нижче.

Комплексний, синтетичний аналіз інформації $є$ першочерговим кроком на шляху визначення цілей і способів їх досягнення та об’єднує такі частини: інформаційну довідку про стан освітнього закладу й відображення перспектив розвитку. Комплексний аналіз $є$ офіційним документом, що подається до органів управління освітою для досягнення зазначених цілей i спрямований на оптимальну організацію роботи освітнього закладу.

Аналіз проблем - метод, що полягає у з'ясуванні різниці між об'єктом, де проблема існує, й іншим, схожим на нього об'єктом, де такої проблеми немає, тобто він використовується у разі, коли причини появи певної проблеми не визначені. У процесі такого порівняння може з'явитися нова ідея щодо причин виникнення проблеми.

Метод аналізу сил впливу дає змогу швидко i наочно охарактеризувати загальну ситуацію, яка виникла. Він використовується для аналізу факторів, що створюють певну ситуацію або проблеми. Завдання методу - пошук шляхів для зменшення негативних впливів та збільшення позитивних.

Метод «дерева цілей». Процес моніторингу спрямований на знаходження пріоритетів вирішення проблем із погляду важливості та терміновості їх вирішення. Сутність методу проявляється у логічному поділі сукупності цілей (розчленування цілей системи більш високого порядку на цілі системи більш низького порядку). Під час аналізу цілей моніторингу освіти керівник опирається на основні глобальні цілі, кожна з яких ділиться на підцілі, які стоять на шляху її досягнення. Із підцілей виводять цілі наступного рівня, продовжуючи діяти так доти, доки не буде досягнутий рівень конкретних цілей настільки, що, на думку того, хто проводить моніторинг, продовжувати подальший розподіл цілей немає сенсу.

Метод оцінки пріоритетів проблем дає змогу 3 погляду важливості, невідкладності тенденцій розвитку (погіршення або поліпшення) якості освіти визначити пріоритети проблем, що визначаються за допомогою відповідної таблиці експертних оцінок, де як експерти можуть виступати керівники закладів, кваліфіковані педагоги тощо. (Приходько, 2010). Отже, застосовуючи зазначені методи моніторингу якості освіти, керівники закладів чи ті, хто відповідають за моніторинг, можуть виявити сукупність проблем і структурувати їх, а отже, забезпечити оптимальний розвиток життєдіяльності закладу вищої освіти. Застосування комплексу методів моніторингу якості освіти сприяє програмному управлінню розвитком освітньої установи й допомагає виокремити джерела інновацій.

Вагомими для дослідника $є$ методи, які дають можливість отримати інформацію безпосередньо від респондента (первинні дані), яка характеризується новизною. До таких методів T. Лукіна відносить: спостереження, опитування (анкетування та інтерв'ювання), тестування, вибірковий метод, які здобули найбільше поширення.

Спостереження у моніторинговому дослідженні - спрямоване, систематичне, безпосередньо візуальне сприйняття і реєстрація значних із погляду дослідника явищ (ситуацій, процесів), що піддаються перевірці та контролю. Отже, спостереження - метод збору 
даних, що полягає у тому, що дослідник веде спостереження за об' єктом за спеціальним планом та заздалегідь визначеними показниками, фіксує всі події, які є вагомими, та аналізує їх.

Найбільш важливі риси спостереження: проводиться за планом і систематизовано (тобто за певними показниками); $\epsilon$ безпосереднім, що дає можливість фіксувати події та елементи людської поведінки у момент їх появи; потребує спеціальної підготовки спостерігача.

Переваги спостереження: безпосередня фіксація чинників; збереження природності у поведінці респондента; об'єктивність в оцінках спостережуваної поведінки; безпосередній аналіз поведінки людей; вільна зміна об'єктів спостереження; незалежність від умінь та навичок респондентів; наявність чіткого плану проведення.

Недоліки спостереження: неможливість дотримання репрезентативності обстежуваної сукупності; складність узагальнення отриманої інформації; неможливість вироблення загальних висновків та рекомендацій щодо удосконалення освітнього процесу; неможливість поліпшення якості освіти і функціонування освітньої системи.

Спостереження частіше використовується, коли формується попереднє уявлення про об'єкт дослідження, на підготовчому етапі роботи, застосовується для перевірки даних, що отримані іншими методами, або ж під час проведення моніторингу якості освіти на інституційному рівні.

Опитування застосовується під час збору відповідей на поставлені запитання і є найбільш поширеним методом збору первинної інформації. Опитування дає можливість отримати конкретну інформацію, яка буде піддаватися статистичній обробці.

За способом проведення опитувань відбувається поділ на анкетування (передбачає заповнення респондентом власноруч спеціального бланку із запитаннями анкети) та інтерв'ювання, під час якого респондент відповідає на запитання усно, а інтерв'юєр фіксує ці відповіді.

Анкетування - метод масового збору інформації від респондента за допомогою спеціально розроблених опитувальників, що називаються анкетами. Бланк анкети може бути як у паперовому, так і в цифровому форматі (Лукіна, 2020).
Види анкетування: за обсягом: суцільне, вибіркове; за способом заповнення анкет: пряме (безпосередне), опосередковане; за способом спілкування: заочне, очне (особисте); за способом поширення анкет: пресове, поштове, роздаткове; за процедурою проведення: групове, індивідуальне (Готлиб, 2005).

Переваги анкетування: незалежність відповідей від того, хто проводить анкетування; достатність часу для відповіді; використання надійного інструменту; стандартизація всіх процедур та самого інструменту; попередня продуманість, виваженість запитань, які формулюються в анкеті; досить широкий спектр питань; порівняна свобода респондента у часі; можливість стандартизації процедури збору даних та їх наступної статистичної обробки.

Недоліки анкетування: неможливість оперативного внесення змін у зміст анкет; відсутність контролю за поверненням анкет; неможливість отримання достовірної інформації про переконання або манеру поведінки респондента в певних ситуаціях; обмеженість окремих видів анкетування (Лукіна, 2020).

Виокремлено багато різновидів анкетних питань. Найбільш поширена така класифікація питань анкети: за формою (закриті, відкриті, напівзакриті, прямі, опосередковані); за конструкцією (дихотомічні, поліваріантні, шкальні, питання-діалоги, питання-ілюстрації); за цілями (змістові, функціональні, які, у свою чергу, поділяються на функціональнопсихологічні (контактні, буферні), питанняфільтри та контрольні питання (питання-тести, питання-пастки)); за змістом (питання про факти, питання про знання, питання про внутрішній стан - думки, ставлення, мотиви тощо) (Новикова, 2000).

Тестування (від англ. testing пробую) - метод психологічної діагностики, що заснований на використанні стандартизованих питань і тестових завдань, що мають шкалу значень, застосовуються для стандартизованого вимірювання індивідуальних відмінностей особистості. Тест - це інструмент тестування, який має задовольняти низку умов, які роблять його засобом вимірювання, а не простим набором запитань і завдань. Будь-який тест складається із тестових завдань. Вони подаються у різній формі та мають різні формати, для яких обчислюються певні характеристики якості тестових завдань. 
Тестування - один із методів педагогічного оцінювання, що здійснюється 3 певною метою i, відповідно, може бути формувальним (поточним) та підсумковим. Для кожного випадку розробляється спеціальний тест, який відповідає меті та завданням цього тестування.

Тести за умови правильного їх використання та розроблення характеризуються високою об'єктивністю, надійністю і точністю вимірювання певних якостей особистості, у нашому разі - освітніх досягнень. Останнім часом усе частіше застосовується тестування за допомогою інформаційних технологій.

Тест повинен: бути валідним (дотримання валідності тесту забезпечує його надійність, але не навпаки); бути придатним для вимірювання того, для чого він розроблений; забезпечувати високу точність вимірювання (мати незначну похибку); бути надійним (результати, одержані 3 його допомогою, мають бути відтворні, a їх значення стійкі); мати шкалу, що забезпечує певний рівень вимірювань. За ступенем підвищення рівня вимірювання шкали поділяються на: номінальні, порядкові (рангові), інтервальні та шкали відношень; тестування повинне бути стандартизованим i сертифікованим (виконання вимоги необхідне у разі проведення підсумкового сертифікаційного тестування). Якщо ж тестування здійснюється протягом освітнього процесу, тобто є поточним, то ця вимога не є обов'язковою.

Усе розмаїття тестових завдань можна подати у чотирьох формах: із вибором правильної відповіді (однієї або кількох); відкритої форми; на встановлення відповідності; на встановлення правильної послідовності.

Тестові завдання з вибором правильної відповіді дають можливість побудови таких варіантів: вибір серед інших неправильних відповідей готової правильної. Логічною основою такої форми тестових завдань $є$ закон виключення третього, сформульований ще Аристотелем. Це означає, що вибір правильної відповіді говорить про формулювання правильного судження у респондента, і навпаки: вибір неправильної відповіді - хибного судження. Отже, третього немає. Із твердження випливає методична порада: у таких тестових завданях обов'язково має бути правильна відповідь. Наявність таких відповідей, як: «правильної відповіді немає», «всі відповіді неправильні», «всі відповіді правильні», заборонена, але, на жаль, такі відповіді часто трапляються в авторських тестах педагогів; здійснення вибору однієї, найбільш правильної відповіді серед кількох відповідей, які $є$ частково правильними. Цей варіант використовується для перевірки знань і вмінь зіставляти інформацію (факти, події, властивості, тощо) і має більш високий рівень складності; вибір кількох запропонованих правильних відповідей, так званий множинний вибір (Лукіна, 2020).

Процес розроблення тестів розпочинається зі структурування навчального матеріалу, визначення основних вимог до оволодіння професійними знаннями та уміннями респондентів за певною спеціальністю. Зовнішня організованість тесту визначається формою правильно сформульованих завдань, коли не виникає логічних, психологічних або інших перепон для розуміння їх змісту та правильного виконання. У тестових завданнях на перший план висуваються важливі елементи професійних знань, а орієнтація на дрібні факти має бути взагалі відсутня.

Необхідно підкреслити незалежність одне від одного тестових завдань (попередні завдання не можуть мати відповіді для наступних завдань). Тести не мають бути довгими і громіздкими (оптимальна довжина 30-60 завдань). Більшість із них потребують простоти за своєю структурою. Орієнтовний час на виконання 30-60 завдань становить 1,5-2 години. Обов'язково звертається увага на вік учасників тестування, рівень мотивації, монотонність виконуваної роботи, часовий поріг стомленості респондентів.

Необхідною є чітка і лаконічна сформульованість тестів. Завдання мають бути без подвійного тлумачення змісту. Варіанти тестових відповідей мають бути однозначними, мати схожість за способом формулювання та форматом подання. Застосування суперечностей і недоведених фактів у тестах не допускається.

У тестових завданнях правильна відповідь не може займати одну й ту саму позицію (розміщуватися або тільки на першій, або тільки на другій тощо позиції) (Гириловська, 2021).

Використання різних методів та інструментів збору інформації під час моніторингового дослідження якості освіти визначається метою дослідження, поставленими завданнями, властивостями самого предмета оцінювання. 
Вибірковий метод - науковий метод відбору одиниць спостереження 3 усього обсягу дослідження, тобто генеральної сукупності (повної сукупності одиниць об'єкта дослідження, щодо якої робляться висновки), що заснований на методах математичної статистики, яка при цьому використовуються. Генеральна сукупність може бути кінцевою (обмеженою за кількістю одиниць) i нескінченною. Наприклад, генеральною сукупністю під час проведення опитування респондентів із питань якості освіти виступає загальна кількість респондентів у країні на період моніторингу (або в регіоні - регіональний моніторинг).

У моніторингу якості освіти формування вибіркової сукупності здійснюється на основі математико-статистичних закономірностей, 3 урахуванням особливостей перебігу управлінських, освітніх, педагогічних процесів. Ця позиція знаходить своє відображення у переліку критеріїв відбору одиниць спостереження.

Основна ідея вибіркового методу: закономірності вибіркової сукупності (закономірності, що виявлені під час вивчення відносно невеликої групи людей) можна поширити на весь об'єкт дослідження (тобто генеральну сукупність).

Переваги вибіркового методу: поширення результатів на всю генеральну сукупність, отримання відомостей про думку різних категорій і груп, що складають цю сукупність, розрахунку помилки вибірки.

Недоліки вибіркового методу: більші фінансові, ресурсні, людські витрати на проведення дослідження та його тривалість порівняно 3 імовірнісними методиками відбору респондентів (Лукіна, 2020).

Висновки те перспективи подальших досліджень. Розглянуто моніторинг освітнього процесу як важливий елемент системи забезпечення якості освітньої діяльності та вищої освіти в Україні. Важливе значення у вдосконаленні системи моніторингу має вибір методів збору інформації про якість освіти. Виокремлено різноманітні групи методів моніторингу, що використовуються для діагностування якості освіти, й охарактеризовано їх у статті. Перспективи подальших досліджень вбачаємо у розгляді особливостей застосовування тестування за допомогою інформаційних технологій.

\section{ЛІТЕРАТУРА:}

1. Євтух, М.Б. (2010) Інноваційні методи оцінювання навчальних досягнень : монографія / М.Б. Євтух, Е.В. Лузік, Л.М. Дибкова ; Держ. вищ. навч. Заклад «Київський нац. економ. ун-т ім. В. Гетьмана». К. : КНЕУ, 248.

2. Приходько В.М. (2010) Парадигми моніторингу якості освіти і педагогічного процесу: (У запитаннях і відповідях). Науково-методичний посібник. Запоріжжя, 215.

3. Пугачева Н.Б. (2003) Управление общеобразовательным учреждением инновационного типа : дис.... доктора пед. наук : 13.00 .01 / Пугачева Наталья Борисовна. Казань, 435.

4. Лукіна Т.О. (2020) Управління якістю загальної середньої освіти: навчально-методичний посібник. Київ : Педагогічна думка. 230.

5. Готлиб А.С. (2005) Введение в социологическое исследование: качественные и количественные подходы. Методология. Исследовательские практики. М. : Изд-во «Флинта», С. 70.

6. Новикова С.С. (2000) Введение в прикладную социологию. Анкетирование. М. : Спорт АкадемПресс. 103.

7. Гириловська І.В. (2021) Теоретичні і методичні основи моніторингу якості професійної підготовки майбутніх кваліфікованих робітників: дис. ... доктора пед. наук: 13.00.04. Київ. 548.

\section{REFERENCES:}

1. Yevtukh, M.B. (2010) Innovatsiyni metody otsinyuvannya navchal'nykh dosyahnen' [Innovative methods of evaluating educational achievements]: monograph / M.B. Yevtukh, E.V. Luzik, L.M. Dybkova; State higher textbook Institution "Kyiv National economy. Univ. V. Hetman ». K. : KNEU, 248.

2. Prykhod'ko V.M. (2010) Paradyhmy monitorynhu yakosti osvity i pedahohichnoho protsesu [Paradigms of monitoring the quality of education and pedagogical process]: (In questions and answers). Scientific and methodical manual. Zaporozhye, 215.

3. Puhacheva N.B. (2003) Upravlenye obshcheobrazovatel'nym uchrezhdenyem ynnovatsyonnoho typa [Management of a general educational institution of innovative type]: dissertation... doctor ped. Sciences: 13.00.01 / Pugacheva Natalia Borisovna. Kazan, 435. 
4. Lukina T.O. (2020) Upravlinnya yakistyu zahal'noyi seredn'oyi osvity: [Quality management of general secondary education]: a textbook. Kyiv : Pedagogical thought. 230.

5. Hotlyb A.S. (2005) Vvedenye v sotsyolohycheskoe yssledovanye: kachestvennye y kolychestvennye podkhody [Introduction to Sociological Research]: Qualitative and Quantitative Approaches. Methodology. Research practices. M. : Flint Publishing House, P. 70.

6. Novykova S.S. (2000) Vvedenye v prykladnuyu sotsyolohyyu.[ Introduction to Applied Sociology]. Questionnaire. M. : Sport AkademPress. 103.7. Hyrylovs'ka I.V. (2021) Teoretychni i metodychni osnovy monitorynhu yakosti profesiynoyi pidhotovky maybutnikh kvalifikovanykh robitnykiv [Theoretical and methodical bases of monitoring of quality of professional training of the future skilled workers]: dis. ... Dr. ped. Science: 13.00.04. Kyiv. 548. 